\title{
POSEBNOSTI IDENTITETA PODGORACA - NJEGOVO OBLIKOVANJE I OBILJEŽJA
}

\author{
Tatjana Tomaić \\ Institut društvenih znanosti Ivo Pilar \\ Područni centar Pula \\ Leharova 1 \\ HR 52100 Pula \\ Tatjana.Tomaic@pilar.hr
}

Istraživanja identiteta pojedinih naroda ili etničkih skupina ne razlikuju se značajno u svom metodološkom pristupu koliko u činjenici da osjećaj zajedništva, što je osnova kolektivnog identiteta, može biti postavljen na potpuno različitim osnovama. Posebnosti koje određuju neki identitet rezultat su prvenstveno povijesnog i institucionalnog konteksta u kojem se je razvijao. Kolektivni identiteti pokazuju bitnu razliku između političkih i kulturalnih koncepata identiteta. Međutim, Podgorci su vjekovima bili zadnja linija obrane kršćanskog svijeta i europske civilizacije od Turaka i islamizacije našeg kontinenta. U kontekstu Vojne krajine, kao institucionalne strukture u kojoj su bili na braniku kršćanstva, Podgorci su izgradili identitet koji bismo mogli definirati obilježjima ne samo kao kulturni već i kao politički.

Istraživačka pitanja: Možemo li stoga, u ulozi čuvara kršćanstva, identitet Podgoraca definirati kao politički identitet koji sadrži zajedničke političke vrijednosti koje se iskazuju oko smisla i pravaca projekta političke zajednice? Mogu li se te identitetske posebnosti analizirati i u kontekstu političke preferencije biračkog tijela kao kršćanskokonzervativno desno orijentirano?

Ključne riječi: identitet, Podgorci, čuvari kršćanstva

\section{Uvod}

Još u antici, pa sve do razvoja ideje o narodnom suverenitetu, bila je poznata vrijednost koju u procesu spoznaje i oblikovanja političke zajednice ima pamćenje i kolektivni identitet. U današnjem suvremenom društvu sam pojam i problematika identiteta postaje sve češće tema znanstvenih rasprava u procesu definiranja identitetskih politika i njihova određivanja kao proizvoda društvene i političke konstrukcije aktera, grupa i institucija. Stoga 
nam istraživanje načina oblikovanja $\mathrm{i}$ obilježja identiteta daje odgovor na pitanje tko smo i kako nas drugi vide. Nije samo jednakost obilježje stvaranja identiteta već je to istovremeno i priznavanje razlika jer je identitet ovisan o priznavanju od drugih. Samim tim možemo utvrditi da identitet nastaje iz procesa povlačenja granica. U ovom slučaju koji istražujemo, granica koju su Podgorci postavili jasno je definirana njihovim sustavom vrijednosti kao zadnja linija obrane kršćanstva.

Analiza temeljena na tehnikama koje čine umijeće komparativnog političkog istraživanja usmjerenog na varijable ${ }^{1}$ dat će odgovore na postavljena istraživačka pitanja: Možemo li stoga, u ulozi čuvara kršćanstva, identitet Podgoraca definirati kao politički identitet koji sadrži zajedničke političke vrijednosti koje se iskazuju oko smisla i pravaca projekta političke zajednice? Mogu li se te identitetske posebnosti analizirati $i$ u kontekstu političke preferencije biračkog tijela kao kršćansko-konzervativno desno orijentirano?

Radi objašnjenja fenomena identiteta dat će se kratki opći pregled teorijskih koncepata kolektivnih identiteta, posebice dvije koncepcije toga identiteta: kolektivnog identiteta na kulturnoj osnovi i političkog identiteta koji je predmet našeg istraživanja. Možemo li staviti u ovaj kontekst Podgorce kao nositelje političkog identiteta na osnovi institucionalne strukture u kojoj su djelovali? Tvrdnju ćemo ispitati s pomoću nezavisne varijable koju ćemo staviti u korelaciju sa selektivnom zavisnom varijablom.

Identitetske posebnosti Podgoraca analizirat ćemo $i$ u kontekstu političke preferencije biračkog tijela kao kršćansko-konzervativno desno orijentirano. Rezultat ćemo dobiti primjenom Lipset-Rokkanov teorijskog modela strukturnih rascjepa koji je u modificiranom obliku primjenjiv i na Istočnu Europu i na analizu hrvatskog stranačkog sustava. ${ }^{2}$

\section{Koncepti identiteta}

Pojam identiteta ima različitu primjenu koja je određena zavisno od samog konteksta znanstvene rasprave o njegovu diskursu: sociologije, antropologije, povijesti, politologije, filozofije. Identitet je razlikovanje neke osobe od drugih osoba po specifičnosti koja je posebna baš toj osobi, ali je moguća i takva ista zajednička poveznica s drugim osobama. Razlikujemo individualni i kolektivni identitet, socijalni identitet, kulturni identitet,

\footnotetext{
${ }^{1}$ R. HAGUE - M. HARROP - S. BRESLIN, 2006, 434-435.

${ }^{2}$ N. ZAKOŠEK, 2002, 75.
} 
politički identitet itd. Individualni identitet mogli bismo definirati kao svijest pojedinca o samome sebi, tj. različitog od drugih. Pripadnost grupi djeluje na individualni identitet, dok se i kolektivni identitet konstruira iz individualnog. Proces je to suodnosa identiteta za koji je značajno da se mijenja i oblikuje vremenom i s drugim različitim socijalnim čimbenicima. Identiteti su u recipročnom odnosu uzajamnog uvjetovanja i nadopunjavanja. Oni su uglavnom višestruki. ${ }^{3}$ Ovisno o osnovi pripadnosti nekoj skupini i razlikovanja na ostale koji joj ne pripadaju nalazimo, prema Anthony Smithu, tri tipske varijante zajedništva koje izgrađuju kolektivni identitet: 1 . kontinuitet iskustva populacije, 2. kolektivno sjećanje na prijelomne točke povijesti, 3. osjećaj zajedničke sudbine. Kolektivno sjećanje novih generacija povezuje identitet kroz osjećaj povezanosti i pripadnosti drugima i njihovom zajedničkom sudbinom kroz sustav vrijednosti i ponašanje. ${ }^{4}$ Proces stvaranja kolektivnog identiteta je prelazak ja u $m i$ utvrđivanjem zajedničkih vrijednosti što čini bitnu karakteristiku nužnu za funkcioniranje samog kolektiva. Prihvaćanje društvenih pravila i njihovo implementiranje $u$ djelovanje individue pokazuje stupanj povezanosti i osnova je nastavka postojanja kolektivnog identiteta. Time se stvara međusobna povezanost $\mathrm{u}$ konstrukciji identiteta.

Prema Turneru i Reynoldsu ${ }^{5}$ teorija socijalnog identiteta temelji se na tri glavna elementa: analiza aspekata psihologije kolektiviteta, specifičnih razlika u statusu različitih skupina te sklonosti da se rješava problem vlastitog identiteta kao pojedinca ili kao člana grupe. Teorija tumači da se variranje između osobnog i socijalnog identiteta odvija u domeni samopoimanja i samopercepcije. Prema teoriji socijalne kategorizacije, čovjek ima nekoliko razina kojima pripada: nadrazinu, međurazinu i podređenu razinu. Upravo međurazina se odnosi na vanjske i vlastite skupine s kojima se individua poistovjećuje ili ne poistovjećuje te ona određuje socijalni identitet svakog pojedinca. ${ }^{6}$

Identitet ima dva aspekta: aspekt zrcala i aspekt zida. Identitet-zrcalo ima funkciju prepoznavanja; moraju se odrediti opće vrijednosti, ciljevi zajednice i dijeliti stavove o zajedničkoj povijesti. U tom smislu vlastite egzistencije i kontinuiteta na kojima je identitet utemeljen, on predstavlja zid koji sprječava grupu da se ne rasformira. ${ }^{7}$

\footnotetext{
${ }^{3}$ E. MORIN, 1995, 199.

${ }^{4}$ A. SMITH, 1998, 30.

${ }^{5}$ J. C. TURNER - K. J. REYNOLDS, 2001, 133-152.

${ }^{6}$ V. ŠAKIĆ - R. FRANC - I. IVIČIĆ - J. MARIČIĆ, 2009, 115-116.

${ }^{7}$ F. CERUTTI, 2006, 27
} 
Sociolog Raymond Breton tvrdi da s obzirom na njegovo podrijetlo postoje tri tipa identiteta: kulturni identitet, utilitaristički identitet i pragmatički identitet. Kulturni identitet nastao je iz zajedničkog nasljeđa primordijalne zajednice kao etničke grupe koja može stvoriti i državu kao rezultat političke volje. Utilitaristički identitet proizlazi iz različitih okolnosti vezanih za interese osoba koje su spremne podržati zajednicu nadajući se nekoj koristi od vlastitog djelovanja u njoj. Kao posljedica spremnosti članova da dijele zajedničku sudbinu, koju pretvaraju u realnost prihvaćajući zajedničke vrijednosti, nastaje pragmatični identitet. Svaka od tih vrsta pripadnosti može nastati na bilo kojoj razini organizacijske strukture društva. ${ }^{8}$

Kriteriji identifikacije identiteta mogu biti različiti; od vjerskih, socioloških, jezičnih, političkih itd. Uspostavljanje samospoznaje vlastite granice otvara nam konstrukciju stranca i jača solidarnost kao i unutarnji poredak socijalnog života. ${ }^{9}$ Kolektvni identiteti su svi izgrađeni. Proces izgradnje sastoji se od mnogih elemenata: tradicije, kolektivnog sjećanja, vjere, produktivnih i neproduktivnih institucija, vlastitih vrijednosti itd. Posebno valja naglasiti da se društveno izgrađivanje identiteta događa u kontekstu koji je označen odnosima moći. Prema toj tvrdnji Castells razlikuje tri oblika i izvora izgradnje identiteta: legitimirajući identitet, identitet otpora i projektni identitet. Svaki od tih tipova izgradnje identiteta dovodi do različitog ishoda u stvaranju društva. Legitimirajući identitet uvode dominantne društvene institucije radi širenja svoje dominacije s obzirom na individue te čini bit Sennettove teorije o autoritetu i dominaciji. Legitimirajući identitet stvara civilno društvo nizom strukturiranih društvenih aktera koji produljuju dinamiku države, ali su po Gramsciju, duboko ukorijenjeni u narodu. Identitet otpora izgrađuje oblike kolektivnog otpora temeljenog na načelima suprotnima od onih koje predstavljaju institucije i stoga dolazi do izgradnje obrambenog identiteta uz pojačavanje granice. Treći tip izgradnje identiteta, projektni identitet, redefinira položaj društvenih aktera u društvu koji njime traže i preobrazbu cijele društvene zajednice. ${ }^{10}$

\section{Identitet Podgoraca}

U analizi kompleksnosti identiteta Podgoraca važno je primijeniti parametre koji će nam dati odgovore na postavljena istraživačka pitanja.

\footnotetext{
${ }^{8}$ M. STUPAR, 2006, 16.

${ }^{9}$ T. CIPEK, 2001, 59-77.

${ }^{10} \mathrm{M}$. CASTELLS, 2002, 17-20.
} 
Identitet Podgoraca postavljamo kao nezavisnu varijablu kroz koju ćemo utvrditi čimbenike koji su oblikovali njihov kulturni identitet kao i sama njegova obilježja kroz povijesni pregled naseljavanja Velebita, sastav stanovništva Podgorja, ali i političke okolnosti koje su formirale njihovo povijesno naslijeđe. Sustav vrijednosti i tradicijske elemente analizirati će se kroz osjećaj pripadnosti zajedničkom jeziku, i posebice vjeri s naglaskom na položaju branitelja kršćanstva te zajedničkoj interpretaciji prošlosti. Analizom postavljenih čimbenika nezavisne varijable uspostavit ćemo korelaciju s indikatorima definiranja političkog identiteta i njegovih elemenata izgradnje. Indikatori zavisne varijable ispitat će je li i u kolikoj mjeri kolektivni identitet Podgoraca istovjetan elementima tvorbe političkog identiteta te prikazati njegove sastojnice koje idu u prilog toj tvrdnji: političko udruživanje kroz zajedničku obranu kršćanstva, institucionalni okvir.

\subsection{Nezavisna varijabla}

- Povijesni pregled naseljavanja Podgorja započinjemo dolaskom Hrvata na Velebit, jer je identitet Podgoraca izvan svake sumnje hrvatski identitet, tako da u tom kontekstu nećemo smatrati nužnost posebnog dokazivanja te tvrdnje, naime sami će rezultati istraživanja, i neovisne i zavisne varijable, kroz kulturni i politički identitet potvrđivati tu činjenicu. Hrvati su amo došli organizirano radi napada na avarske horde kao saveznici bizantskog cara Heraklija. Osnivali su svoja pastirska naselja i obrađivali zemlju, sve do napada Turaka koji počinju 1514. godine. Pod naletom turskih upada iz Podgorja se nakon poraza kod Mohača 1526. godine iselio veliki broj stanovnika većinom na otoke Rab, Krk i Pag i grad Senj, u kojem je osnovana Primorska krajina koja je zauzimala područje cijelog Podgorja (od Senja do Baga) i Primorje do Novoga. ${ }^{11}$ Senjsko zapovjedništvo budno je čuvalo Podgorje od turskog osvajanja. Vojna krajina ili granica uspostavljena je 1579. godine radi bolje i organiziranije obrane od Turaka. U tom posebnom pograničnom području austrijske vojne vlasti uvele su poseban režim i podijelile je na dva generalata. Hrvatska krajina bila je dio Karlovačkog generalata, a osnovane su još Otočka i Lička pukovnija. Otočka pukovnija pokrivala je sjeverni i srednji dio primorja i podgorja i dijelila se na Svetojursku i Jablanačku satniju. Ličkoj pukovniji i Smiljanskoj satniji područje djelovanja bio je južni dio Velebita.

\footnotetext{
${ }^{11}$ A. LEMIĆ, 2013, 31-32.
} 
- Sastav stanovništva Podgorja prvenstveno je rezultat planskog doseljavanja koje su austrijske vlasti provodile radi naseljavanja tih pustih velebitskih krajeva i radi potrebe obrane i funkcioniranja Krajine. Još 1605. senjski kapetan Danilo Frankov u dogovoru s grofovima Zrinskim počeo je, u dva navrata, preseljenje oko pedesetak obitelji iz Krmpota kraj Zemunika prvo kod Fužina, a kasnije su selili u Senj i podvelebitsko primorje. ${ }^{12}$ Prvi val doseljavanja u 17. stoljeću čine bunjevci iz sjeverne Dalmacije (Nin, Benkovac, Biograd) i Gorskog kotara (Krmpote, Krivi Put, Lič, Veljun, Sv. Jakov). Drugi val naseljavanja bio je krajem 17. i tijekom 18. stoljeća kada se doseljava stanovništvo iz Senja i Vinodola te otoka Cresa, Krka i Lošinja. U Krajini je tijekom stoljeća nastalo stanovništvo autohtonih Hrvata i prebjeglih hrvatskih kmetova te brojnih vlaških prebjega. Život stanovništva se drastično promijenio tako da su stočari i seljaci postali vojnici koji su se morali prilagoditi vojničkim pravilima i disciplini jer su nove političke okolnosti donijele stanovništvu obvezu služenja vojske. ${ }^{13}$ Ukidanjem područja Vojne krajine 15. srpnja 1881. godine normaliziralo se gospodarstvo uz stočarstvo, ratarstvo i ribarstvo kojima je lokalno stanovništvo ponovno organiziralo svoju kršku svakodnevnicu.

- Jezik kao sredstvo komuniciranja nužna je sastavnica identiteta u procesu njegova formiranja i definiranja. Kao temeljno sredstvo naše socijalizacije u vlastitoj grupi, jezik izražava i oblikuje njezinu stvarnost što se tumači lingvističkim determinizmom. ${ }^{14}$ Stoga je jezik kao kulturni konstrukt jedna od tri sastavnice koje je P. R. Vitezović idejno izložio u svojoj teoriji o oblikovanju hrvatske nacije. ${ }^{15}$ Vitezović je u svom političkom spisu Croatia rediviva iz 1700. godine zastupao tezu o jedinstvu hrvatskih zemalja i značaju hrvatskog jezika smatrajući ga središnjim slavenskim jezikom. ${ }^{16}$ Takva ideja kasnije je argumentirana u stavovima hrvatskih preporoditelja koji su slijedili Herderovu teoriju nacije i njegovih sljedbenika po kojoj jezik grupe omogućava osobeno poimanje svijeta, različito od govornika drugih jezika. Vjerovanje da su narodi prirodan fenomen iz čije zajedničke prošlosti nastaje kulturna i jezična kohezija, po etničkim nacionalistima, ujedinjuje ih u jednu političku

\footnotetext{
${ }^{12}$ A. LEMIĆ, 2013, 32.

${ }^{13}$ Hrvatska Vojna krajina bila je podijeljena na manje teritorijalne jedinice; Karlovačku (Lika i Kordun), Varaždinsku (Bilogora i Podravina) i Zagrebačku kapetaniju (Banija).

${ }^{14}$ S. WRIGHT, 2010, 2.

${ }^{15}$ P. R. VITEZOVIĆ, 1997.

${ }^{16}$ T. CIPEK, 2001, 59-77.
} 
zajednicu. ${ }^{17}$ Takva politička zajednica oblikovala je identitet Podgoraca koji su od 1578. bili pod potpunom kontrolom Beča do 1881. kada su Hrvatska i Slavonska Vojna krajina vraćene Kraljevini Hrvatska-Slavonija. ${ }^{18}$

- Najvažnija odrednica koja je obilježila identitet Podgoraca i njihovu ulogu u kršćanskoj Europi kao kriterij identifikacije je vjera. Podgorci su branili i obranili kršćansku Europu od islama i Turaka. Stoga je to duboko ukorijenjeno u njihov identitet graničara i branitelja svetog. Mogli bismo slobodno reći da je identitet Podgoraca po modelu realni identitet Hrvata u analiziranim elementima. Hrvati su, po Europi i europskoj povijesti, branitelji kršćanstva pa je samim time taj religijski čimbenik sastavni dio identiteta Hrvata koji je ugrađen iz identiteta Podgoraca.

Političke okolnosti koje su formirale njihovo povijesno nasljeđe na temelju kulturnih predispozicija počivaju na snažnoj mobilizaciji oko specifičnih etičkih, kulturnih i religioznih vrijednosti koje su odredile Podgorce $\mathrm{u}$ zajedničkoj interpretaciji povijesti. ${ }^{19}$

\subsection{Zavisne varijable}

- U slučaju političkog identiteta postoji razvijen osjećaj pripadnosti nekom političkom sustavu temeljen na pozitivnom stajalištu prema njegovim vrijednostima. Spremnost ljudi za zajedničke političke institucije i suglasnost oko smisla same zajednice pretpostavka je za nastanak političkog identiteta. U Podgoraca to prepoznajemo kao političko udruživanje kroz zajedničku obranu kršćanstva.

- Institucionalni okvir koji je ostvaren Vojnom krajinom pruža bitan element za izgradnju političkog identiteta. Institucionalni okvir Vojne krajine otvorio je mogućnost stvaranju političkog identiteta Podgoraca jer je glavno uporište političkog identiteta legitimnost kao sredstvo služenja jednim pravnim temeljem vlasti, izvan njegove faktičnosti. ${ }^{20}$

Nacionalni identitet je osnovni oblik kolektivnog političkog identiteta. Konstuktori nacionalnog identiteta osim aktivne uloge elita su zajedničke

${ }^{17}$ S. WRIGHT, 201, 31.

${ }^{18}$ Službeni naziv samosvojnog kraljevstva unutar Austro-Ugarske nastalog sklapanjem hrvatsko-ugarske nagodbe 1868. bio je Trojedna Kraljevina Hrvatska, Slavonija i Dalmacija ili neslužbeno Trojednica.

${ }^{19}$ Skoro svaki dvanaesti stanovnik Vojne krajine služio je kao vojnik dok je u ostalom dijelu Habsburške Monarhije to bio tek svaki šezdeset drugi stanovnik.

${ }^{20}$ F. CERUTTI, 2006, 40-41. 


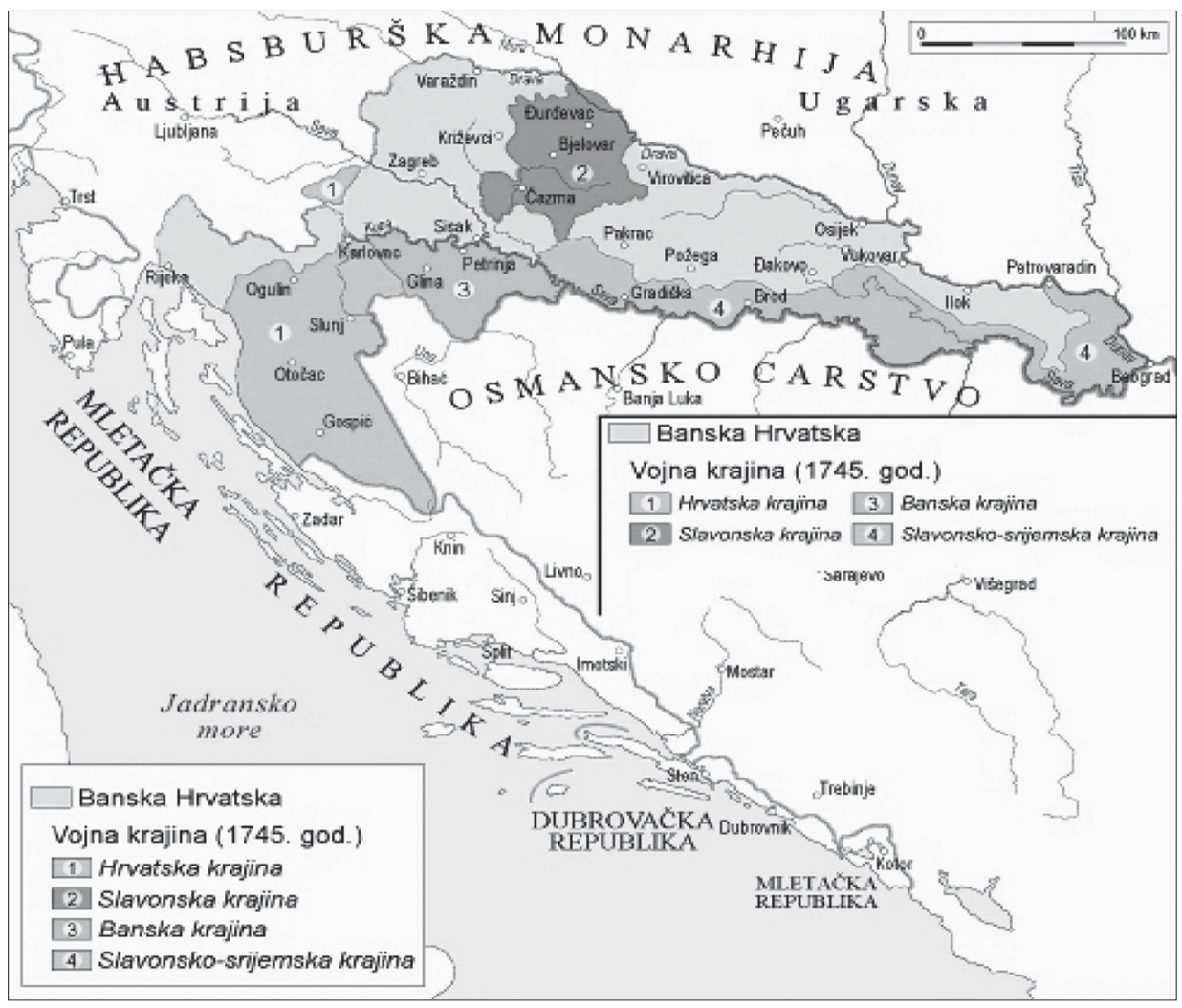

Sl. 1. Vojna krajina, izvor: http://www.enciklopedija.hr/natuknica.aspx?id=36410

kulturne tradicije, običaji, sjećanja, simboli, aktivno identificiranje s nacionalnom državom. Uvjet nastanka nacionalnog identiteta je pokušaj političke elite da utječe na snažno identificiranje s nacionalnom državom i želja stanovništva za kolektivnom povezanošću. Sam nacionalni identitet nastaje procesom unutarnje povezanosti i vanjskog definiranja granica stvarajući vremenski kontinuitet svoje jezgre utemeljene na zajedničkoj kulturi, povijesnim sjećanjima i mitovima, zajedničkom teritoriju i zakonskim pravima. Ali Podgorci nisu imali svoju zajedničku nacionalnu državu. Svoja uvjerenja oblikovana u $m i$ definirana prema pripadnicima ne-mi grupe u kontekstu povijesnih događanja potvrđuje treći kôd nacionalnog identiteta po tipologiji Samuela Noaha Eisenstadta i Bernarda Giesena koji kolektivni identitet oblikuje na osnovi svetoga. ${ }^{21}$ Tumačimo to

${ }^{21}$ T. CIPEK, 2001, 62-63. 
sakralno kao Bog, kao vjera. Takav kolektivni identitet svoj izraz dobiva u religiji kao okosnici identiteta. Prikazana teorija potvrđuje postavljenu tezu o vjerskom elementu koji je kroz ulogu branitelja kršćanstva prepoznat kao dominantan identitetski kriterij Podgoraca. Mogli bismo utvrditi da je identitet Podgoraca dijelom ostvaren kao politički identitet utemeljen prvenstveno na četvrtom elementu Ceruttijeve tvrdnje o institucionalizaciji kao faktoru zadovoljavanja zahtjeva stabilizacije i kodificiranja političkog identiteta. ${ }^{22}$

\section{Političke preferencije biračkog tijela kao identitetski čimbenik}

Identitet Podgoraca analizirat ćemo i u politološkoj obradi izbornih podataka kao mjernog pokazatelja političkih preferencija birača zadanog područja. Politički svjetonazor i sustav vrijednosti koji definira određene profile birača usporedit ćemo s rezultatima lokalnih izbora u Ličko-senjskoj županiji i staviti u korelaciju s modelom strukturnih razlika koji pokazuje duboke razine društvenih sukoba i suprotstavljena identitetska pozicioniranja. Po razmještaju stranaka u hrvatskom političkom prostoru i njihovim biračima ispitat ćemo kakvi su Podgorci birači i je li njihova dominantna identitetska karakteristika-branitelji kršćanstva, primjenjiva u identifikaciji s kršćanskokonzervativno desno orijentiranim političkim strankama.

\subsection{Rezultati lokalnih izbora u Ličko-Senjskoj županiji $i^{23}$}

Lokalni izbori uzeti su kao relevantna analiza iako se granice Hrvatske krajine $^{24}$ i Ličko-senjske županije ${ }^{25}$ površinski ne poklapaju u potpunosti ali su korištene kao jedinice relevantne za provedeno ispitivanje.

${ }^{22}$ F. CERUTTI, 2006, 59.

${ }^{23}$ Ličko-senjska županija (IX), administrativno-teritorijalna jedinica u gorsko-primorskome dijelu Hrvatske sa sjedištem u Gospiću. Sastoji se od 8 općina (Brinje, Donji Lapac, Karlobag, Lovinac, Perušić, Plitvička jezera, Udbina i Vrhovine) i četiri naselja s gradskim statusom (Gospić, Novalja, Otočac, Senj). Ličko-senjska županija ima 255 naselja. - http://www.enciklopedija.hr/ natuknica. $\operatorname{aspx} ? \mathrm{id}=36410$

${ }^{24}$ Kada je Vojna krajina 1849. proglašena zasebnom krunskom zemljom Habsburške Monarhije, obuhvaćala je $200000 \mathrm{~km}^{2}, 1010000$ stanovnika, 12 gradova, 9 trgovišta i 1760 sela. - http://www.enciklopedija.hr/natuknica.aspx?ID=65199

${ }^{25}$ Po površini teritorija među županijama u Republici Hrvatskoj, najveća je županija s 5.350,50 km² i obuhvaća 9,46\% državnog teritorija.-http://www.licko-senjska.hr/index.php/ozupaniji/opci-podatci 


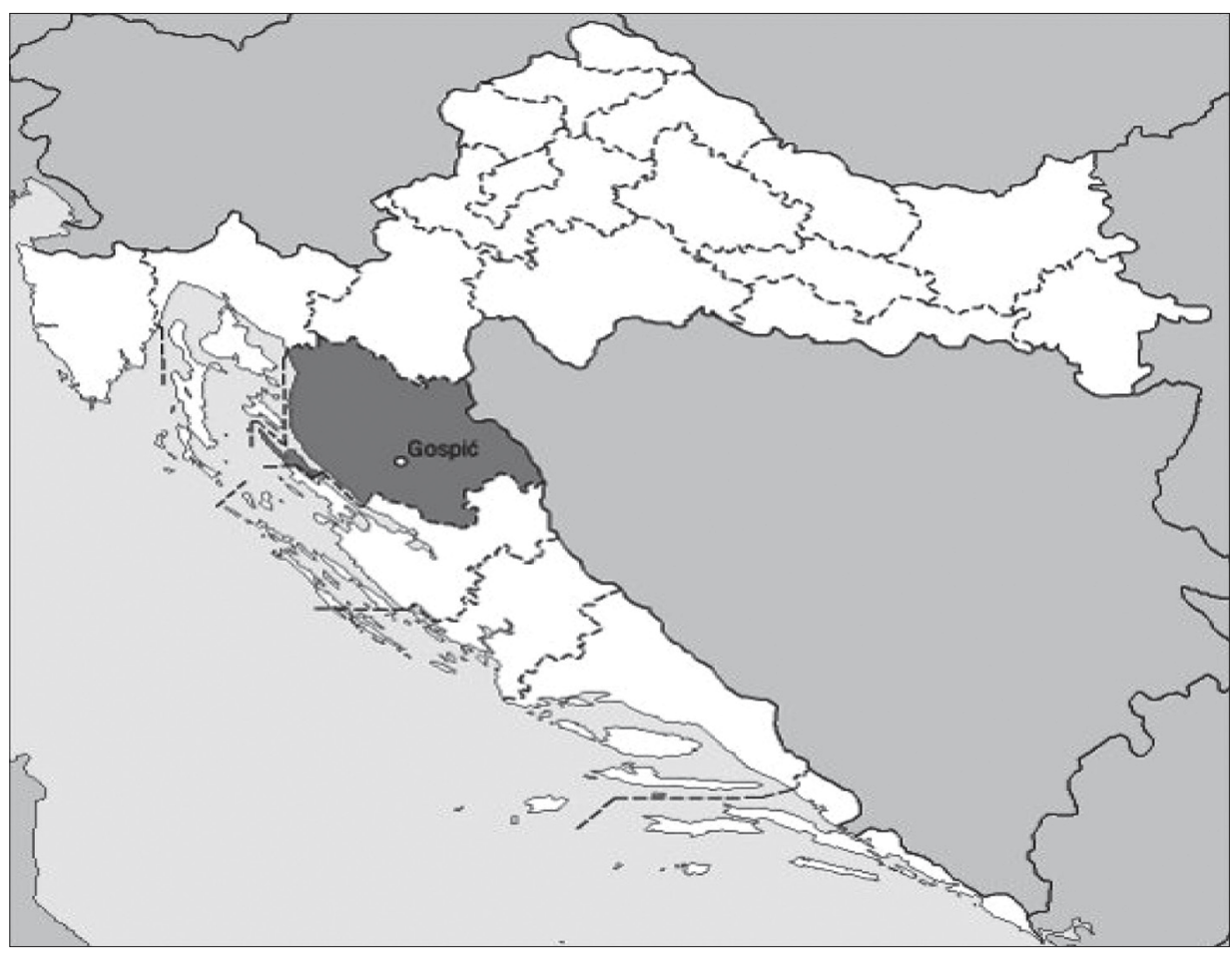

S1. 2. Ličko-senjska županija, ${ }^{26}$ izvor: http://www.enciklopedija.hr/natuknica. aspx?id=36410

Redoviti lokalni izbori na području cijele zemlje (ne računajući prijevremene) dosad su održani 1990., 1993., 1997., 2001., 2005., 2009. i 2013. godine. Prvi višestranački demokratski izbori na lokalnoj razini održani su istodobno s parlamentarnima u travnju i svibnju 1990., i to prema odredbama istog zakona. ${ }^{27}$ Nakon donošenja novog Ustava 1990. i

${ }^{26}$ Popis 2001.- Hrvati 46245 ili 86,15\%, Srbi 6193 ili 11,54\%. Popis 2011.- Hrvati 42857 ili $84,15 \%$, Srbi 6,949 ili 13,65\%. http://www.likaplus.hr/ls_zupanija/politika/sto_pokazuje_zadnji_ popis_stanovnistva/default.aspx

${ }^{27}$ Riječ je o Zakonu o izboru i opozivu odbornika i zastupnika iz 1990. kojim se uređivao izbor i opoziv odbornika u tadašnje skupštine općina i gradskih zajednica općina kao predstavničkih tijela lokalne samouprave. Kao i tadašnji Sabor Socijalističke Republike Hrvatske, i skupštine općina i gradskih zajednica općina imale su tri vijeća: Vijeće udruženog rada, Društveno-političko vijeće i Vijeće mjesnih zajednica (skupštine općina) odnosno Vijeće općina (skupštine gradskih zajednica općina). Sukladno modelu za parlamentarne izbore, i ovi su izbori zakonski uređeni prema većinskom izbornom sustavu s dva izborna kruga i jednomandatnim jedinicama. 
osamostaljenja države 1991., prvi su lokalni izbori održani u veljači 1993. istodobno sa izborima za Županijski dom Sabora Republike Hrvatske. ${ }^{28}$ Izbori za članove predstavničkih tijela lokalne samouprave i uprave održani su 13. travnja 1997., i to prema normama Zakona o izmjenama i dopunama zakona o izboru članova predstavničkih tijela jedinica lokalne samouprave i uprave iz 1996. Godine 2001. postojeći je izborni model promijenjen u razmjerni sustav sukladno odredbama Zakona o izboru članova predstavničkih tijela jedinica lokalne i područne (regionalne) samouprave iz 2001. ${ }^{29}$ Prvi su izbori prema ovom modelu održani u svibnju 2001., a ista su zakonska rješenja zadržana do danas. Pregledom korištenja različitih modela izbornih sustava i metode obrade podataka analizirati ćemo lokalne izbore za Županijsku skupštinu Ličko-senjske županije ${ }^{30}$ počevši od 1993., od uspostave županijskog ustrojstva Republike Hrvatske do zadnjih održanih lokalnih izbora 2013. godine. Politološki pristup prikazuje dinamiku djelovanja političkih stranaka i njihovu konstantu kroz izborne cikluse. Nepostojanje demokratske tradicije koja bi doprinijela većoj participaciji građana u osiguranju sredstva legitimnosti političkih institucija nije fenomen isključivo vezan za Ličko-senjsku županiju, niti za cijelu Republiku Hrvatsku, već zahvaća države Srednje i Istočne Europe koje su se transformirale 90-ih godina 20. stoljeća iz autokratskih sustava u demokratske. Hrvatska tranzicija ima i svoja specifične karakteristike: stvaranje države i istovremenog obrambenog Domovinskog rata. Proces stvaranja države dobiva prioritet u usporedbi s nastavkom procesa demokratizacije. ${ }^{31}$ Hrvatska je uspješnim vojnim akcijama oslobodila veći dio svojega teritorija, dok je mirna reintegracija Podunavlje pod nadzorom UN-a završena 1998. godine.

${ }^{28}$ Umjesto ranijih općina i gradskih zajednica općina, nove jedinice lokalne samouprave postale su općine, gradovi i županije te kotari s posebnim samoupravnim položajem koji su u međuvremenu ukinuti. Istovjetno izbornom modelu za izbore u Zastupnički dom, lokalni su izbori također provedeni prema segmentiranom ili kombiniranom izbornom modelu, a zakonska im je osnova bio Zakon o izboru članova predstavničkih tijela jedinica članova lokalne samouprave i uprave iz 1992.

29 Prema tom se Zakonu članovi općinskih i gradskih vijeća te županijskih skupština i Gradske skupštine Grada Zagreba biraju proporcionalnom izbornom metodom u kojoj cijelo područje jedinice lokalne i područne (regionalne) samouprave čini jednu izbornu jedinicu, dok jedinstveni izborni prag za pojedinu listu iznosi najmanje 5\% važećih glasova birača.

${ }^{30}$ Prema popisu stanovništva 2011. godine Županija ima 50927 stanovnika, što je u odnosu na 2001. g. kada je imala 53677 stanovnika značajan pad od 5,12\%. Gustoća naseljenosti je pala $\mathrm{s} 10,03 \mathrm{st} / \mathrm{km}^{2}$ na $9,52 \mathrm{st} / \mathrm{km}^{2}$, što je znatno ispod prosjeka za Republiku Hrvatsku $\left(75,16 \mathrm{st} / \mathrm{km}^{2}\right) \mathrm{i}$ čime je najrjeđe naseljena županija.- http://www.licko-senjska.hr/index.php/o-zupaniji/opci-podatci

${ }^{31}$ N. ZAKOŠEK, 2002, 12. 
Tablica 1. Rezultati lokalnih izbora u Ličko-senjskoj županiji za Županijsku skupštinu

\begin{tabular}{|c|c|c|c|c|c|c|c|}
\hline & $\begin{array}{l}\text { LOKALNI } \\
\text { IZBORI }\end{array}$ & 1993. & 1997. & 2001. & 2005. & 2009. & 2013. \\
\hline & Ukupno birača & 47689 & 48342 & 57281 & 59237 & 58469 & 48151 \\
\hline & Glasovalo birača & 31206 & 31248 & 28428 & 26731 & 29550 & 25466 \\
\hline & $\begin{array}{l}\text { U postotku } \\
\text { glasovalo }\end{array}$ & $65,4 \%$ & $64,64 \%$ & $49,62 \%$ & $45,13 \%$ & $50,54 \%$ & $52,86 \%$ \\
\hline & Važeći listići & 29950 & 30104 & 27362 & 25907 & 28030 & 23737 \\
\hline & $\begin{array}{l}\text { Ukupan broj } \\
\text { vijećnika u ŽŠS }\end{array}$ & 40 & 45 & 45 & 45 & 45 & $31+1$ \\
\hline \multirow{3}{*}{$\begin{array}{l}\text { Hrvatska } \\
\text { demokratska } \\
\text { zajednica - HDZ }\end{array}$} & Broj glasova & 22341 & 17975 & 10797 & $13226^{32}$ & $19584^{33}$ & $13841^{34}$ \\
\hline & Postotak & $74,6 \%$ & $59,7 \%$ & $39,45 \%$ & $51,05 \%$ & $69,86 \%$ & $58,31 \%$ \\
\hline & Broj vijećnika & 35 & 34 & 20 & 26 & 32 & $19+1^{35}$ \\
\hline \multirow{3}{*}{$\begin{array}{l}\text { Hrvatska stranka } \\
\text { prava - HSP }\end{array}$} & Broj glasova & & & 1997 & 1775 & & \\
\hline & Postotak & & & $7,29 \%$ & $6,85 \%$ & & \\
\hline & Broj vijećnika & & & 3 & 3 & & \\
\hline \multirow{3}{*}{$\begin{array}{l}\text { Hrvatska } \\
\text { seljačka stranka } \\
\text { - HSS }\end{array}$} & Broj glasova & 2859 & 5474 & 3831 & $5231^{36}$ & & \\
\hline & Postotak & $9,2 \%$ & $18,18 \%$ & $14,02 \%$ & $20,19 \%$ & & \\
\hline & Broj vijećnika & 2 & 7 & 7 & 10 & & \\
\hline
\end{tabular}

Lokalni izbori u pravilu imaju puno manju izlaznost od izbora na parlamentarnoj razini jer ih birači politički percipiraju kao nevažne što rezultira manjom motiviranošću.

Poštujući načelo ciljane vrijednosti kao temeljne političke kategorije selektivno su odabrani izborni rezultati stranaka koji se uklapaju u koncepciju

${ }^{32}$ U koaliciji s DC-om (Demokratski centar).

${ }^{33}$ U koaliciji s HSS-om, HSP-om i HSLS-om.

${ }^{34}$ U koaliciji s HSS-om, HSP, HSP AS (Hrvatskom strankom prava dr. Ante Starčević) i HSU (Hrvatska stranka umirovljenika).

${ }^{35} \mathrm{Na}$ temelju članka 107, st. 3., 4. i 5 Zakona ostvaruje se pravo na dodatnog člana u županijskoj skupštini.

${ }^{36} \mathrm{U}$ koaliciji sa SDP-om i HNS-om. 
političkog prostora omeđenog teritorijalno-kulturnim i ideološko-kulturnim rascjepom kao i prostora omeđenog ideološko-kulturnim i socioekonomskim rascjepom. U oba slučaja rezultati nam pokazuju da su stanke desnog centra i desnice: Hrvatska demokratska zajednica (HDZ), Hrvatska seljačka stranka (HSS), Hrvatska stranka prava (HSP), Hrvatska stranka prava dr. Ante Starčević (HSP AS) i Demokratski centar (DC) stabilni pobjednici lokalnih izbora u Ličkosenjskoj županiji. ${ }^{37}$ Iako je nakon lošeg rezultata izbora 2005 . Hrvatska socijalnoliberalna stranka (HSLS) bila je na izborima 2009. partner desnoj koaliciji HDZ-a, HSS-a i HSP-a, ali je njezino pozicioniranje u hrvatsko političkom prostoru, koji je omeđen strukturalnim rascjepima, u grupaciji stranaka ljevice. ${ }^{38}$ Analiza izbornih rezultata pokazuje da je HDZ pobjednik svih lokalnih izbora s najvišim postotkom osvojenih glasova. Od šest izbornih ciklusa, u prva tri samostalno izlazi na izbore te 1993. i 1997. dobiva natpolovičnu većinu (74,6\% i 59,/\%), dok ukupan zbroj sa HSS-om kao strankom desnog bloka čini 83,8\% 1993. i 78,5\% 1997. Na izborima 2001. HDZ osvaja $39,45 \%$ te ako pribrojimo rezultate HSS-a i HSP-a, onda desne stranke postižu ukupno $60,76 \%$. Na sljedeća tri izborna ciklusa HDZ ulazi u koalicije: 2005 . s DC-om dobiva 51,05\%, a ako pribrojimo HSS i HSP dobivamo 78,09\% osvojenih glasova desnice. HDZ koalicijama 2009. i 2013. u kojima su mu partneri i HSS i HSP osvaja 69,86\% i 58,31\%. Analiza izbornih rezultata kroz izborne cikluse ukazuje na uvjerljivu pobjedu demokršćansko-pučkih konzervativnih stranaka.

Iako ovim istraživanjem nisu obuhvaćeni parlamentarni izbori, navest ćemo samo da je kandidatkinja HDZ-a, desnog centra i stranaka pozicioniranih na desnici Kolinda Grabar Kitarović u drugom krugu predsjedničkih izbora (održanih 11. siječnja 2015.), u IX. izbornoj jedinici, koju čini i Ličko-senjska županija ${ }^{39}$, ostvarila najbolji rezultat od $67,11 \%{ }^{40}$

${ }^{37}$ Nije posebno spomenuta Hrvatska stranka umirovljenika (HDU) kao koalicijski partner desnoj koaliciji na izborima 2013. jer njezin program ne počiva ni na programskoj ni ideološkoj komponenti, nego isključivo interesnoj.

${ }^{38}$ HSLS-ovi izborni rezultati za Županijsku skupštinu variraju od vrijednosti 15,2\% 1993., 10,59\% 1997. do 7,8\% 2001. dok 2005. nisu osvojili vijećnički mandat. Na izborima 2013. ostvarili su $11,67 \%$ (3 vijećnika).

${ }^{39}$ IX. izborna jedinica obuhvaća Ličko-senjsku županiju, Zadarsku županiju, Šibenskokninsku županiju i sjeverni dio Splitsko-dalmatinske županije, i to: područje Ličko-senjske županije u cijelosti, područje Zadarske županije u cijelosti, područje Šibensko-kninske županije u cijelosti, sjeverni dio Splitsko-dalmatinske županije (gradovi i općine: Dicmo, Dugopolje, Hrvace, Kaštela, Klis, Lećevica, Marina, Muć, Okrug, Otok, Prgomet, Primorski Dolac, Seget, Sinj, Trilj, Trogir, Vrlika). http://www.sabor.hr/Default.aspx?sec=100

${ }^{40} \mathrm{http}: / /$ www.izbori.hr/106pre/rezult/2/rezultati.html 


\subsection{Rascjepi kao temelj hrvatskoga stranačkog sustava}

Strukturalni rascjepi pokazuju duboko ukorijenjene podjele u Republici Hrvatskoj. Oni se zasnivaju na dugoročnim oprekama ili sukobima, koji uključuju različite društvene skupine s posebnim svjetonazorima, vrijednosnim orijentacijama i obrascima ponašanja. ${ }^{41}$ Nastanak i postojanje svakog od strukturalnih rascjepa u društvu rezultira uspostavljanjem političke dihotomije koja se odražava i na strukturu stranačkog sustava. ${ }^{42}$

U hrvatskom društvu postoje tri strukturalna rascjepa (povijesno nastalih polarizacija) na kojima je zasnovan stranački sustav: rascjep centar-periferija, rascjep tradicionalizam-modernizam i rascjep etatističko-egalitarnom socijalnom orijentacijom ili tržišno-poduzetničkom socijalnom orijentacijom.

Položaj biračkog tijela hrvatskih stranaka u političkom prostoru određen je teritorijalno-kulturnim rascjepom, ideološko-kulturnim rascjepom i socioekonomskim rascjepom. ${ }^{43}$

Teritorijalno-kulturni rascjepi rezultat su procesa definiranja teritorijalnih i simboličkih granica nacionalne države (rascjepi između centra i periferije, etničke većine i manjine, sukob oko centralizacije i decentralizacije). Ideološkokulturni rascjepi odgovaraju polarizaciji interesa u različitim koncepcijama kulturnog identiteta (tradicionalizam-modernizam, religioznost-sekularizam) te predstavljaju sukob različitih vrijednosnih orijentacija i pogleda na svijet. Socioekonomski rascjepi rezultat su sukoba oko pristupa proizvodnim resursima i kontrole nad njima. ${ }^{44}$

Stranački rascjep u Republici Hrvatskoj još uvijek je zasnovan na nacionalno identitetskim i kulturnim varijablama, a ne na ekonomsko institucionalnim. Hrvatski stranački sustav pokazuje unikum, a to je stabilnost biračkog tijela HDZ-a nasuprot izrazite nestabilnosti biračkog tijela lijevo liberalnih stranaka. Glasovanje kao izraz ideološke identifikacije i stranačke preferencije prvenstveno je uvjetovano prikazanim rascjepima u kojima

${ }^{41}$ Strukturalni rascjepi: opisuju bipolarne ili dihotomne konstelacije interesa; uključuju djelovanje elita i masa; povijesno su nastali političkom mobilizacijom grupnih vrijednosti ili interesa; pretpostavljaju podudarnost društvenog identiteta skupine s političkom/stranačkom preferencijom, iako mogu postojati skupine bez adekvatnog političkog izraza ("latentni rascjepi") kao i stranke bez socio-kulturne osnove; rascjepi objašnjavaju dugoročnu stabilnost stranačkog sustava i biračkog ponašanja, ne mogu objasniti kratkoročnu volatilnost birača.

${ }^{42}$ S. M. LIPSET, S. ROKKAN, 1967. http://janda.org/c24/Readings/Lipset\&Rokkan/ Lipset\&Rokkan.htm

${ }^{43}$ N. ZAKOŠEK, 2002, 94.

${ }^{44}$ N. ZAKOŠEK, 2002, 8-90. 


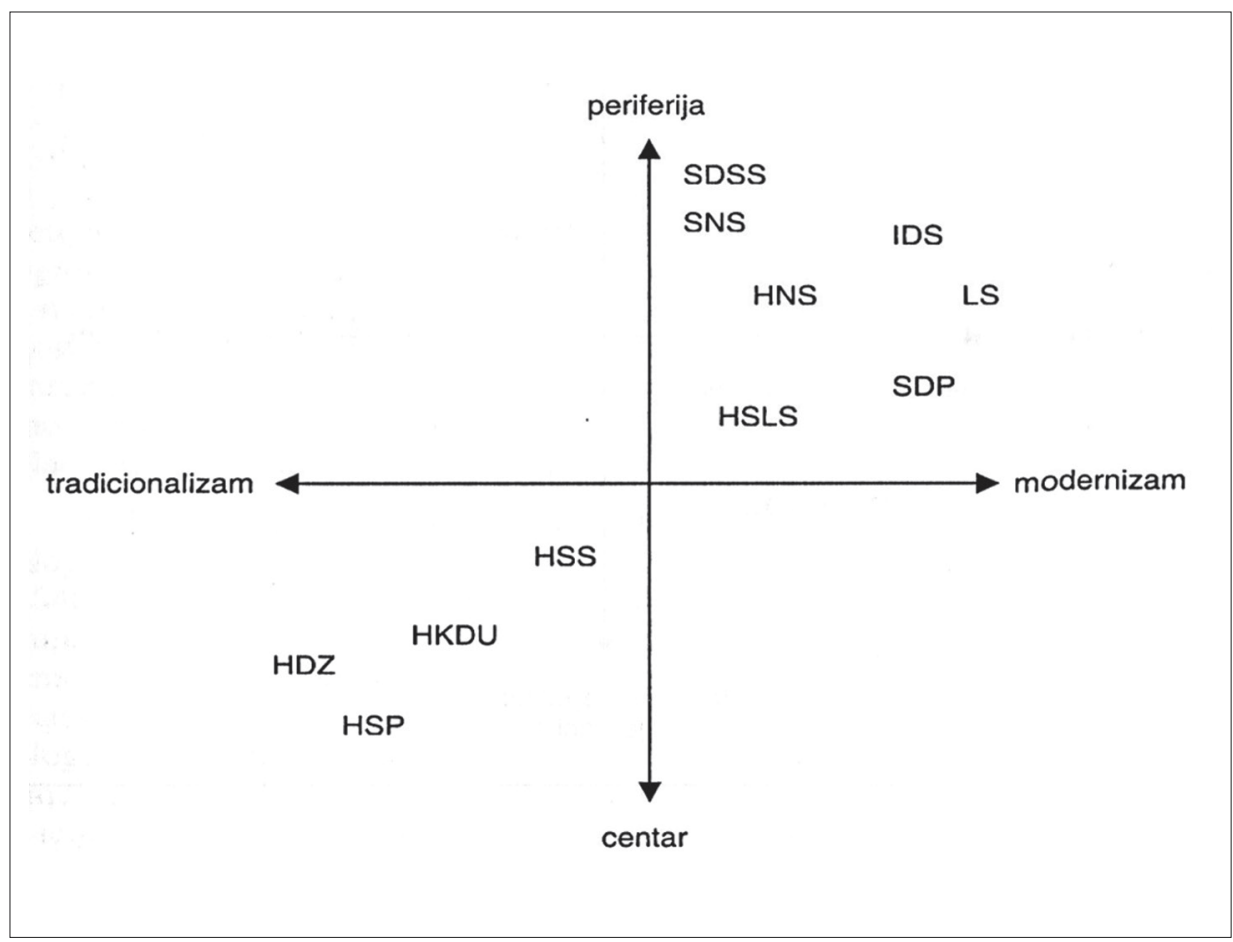

Skica 1. Razmještaj stranaka u dvodimenzionalnom prostoru omeđenom teritorijalnokulturnim i ideološko-kulturnim rascjepom, izvor: N. ZAKOŠEK, 2002, 95.

samoidentifikacija Podgoraca-birača, u ovom slučaju katoličkih vjernika, čini jaku poveznicu s hrvatskim nacionalizmom i njihovim shvaćanjem hrvatskog identiteta što se podudara s rascjepom tradicionalizam-modernizam i rascjepom centar-periferija. HDZ-a, HSP-a i HSS-a nalaze se unutar prostora tradicionalizam i centar. ${ }^{45}$

Povijesno nastala polarizacija određena je sustavom vrijednosti temeljenim na pripadanju ideološko-političkom bloku desnice s kojom su se Podgorci politički identificirali. Izborni rezultati pokazuju da je njihova biračka preferencija HDZ, stranka desnog centra s kojom su se u najvećoj mjeri identificirali na temelju vlastitog sustava vrijednosti i identiteta. Državotvornost HDZ-a zasigurno je jedan od glavnih razloga njegovih uvjerljivih izbornih pobjeda koji Ličko-senjsku županiju učvršćuju kao stabilnu utvrdu desnice.

${ }^{45}$ N. ZAKOŠEK, 2002, 93-94. 


\section{Zaključak}

Analiza identiteta Podgoraca pokazala je da su svojom ulogom branitelja kršćanstva izgradili politički identitet institucionaliziran formiranjem i postojanjem Vojne krajine koja je u europskoj povijesti poznata ne samo kao zaseban politički nego i vojni, gospodarski i društveni fenomen. Takav politički identitet Podgorci su ugradili i u identitetska obilježja hrvatskog nacionalnog identiteta koji je prepoznatljiv u Europi kao zadnja linija obrane kršćanskog svijeta i obrane svetoga.

Religija kao dominirajući čimbenik identitetskog oblikovanja iskazuje se i kroz identifikaciju birača $\mathrm{s}$ demokršćansko-pučkim konzervativnim strankama koje nadmoćno pobjeđuju u Ličko-senjskoj županiji, ne samo na lokalnoj razini nego i parlamentarnoj, a koja zbog različite strukture izbornih jedinica nije bila predmet naše aktualne analize.

Provedeno istraživanje u kolikoj mjeri je identitet Podgoraca politički identitet ostvaren bez nacionalne države u vrijeme političke institucije Vojne krajine otvorilo je nova pitanja vezana za samu metodologiju. Bi li studija slučaja pokazala slične ili različite rezultate i u drugim dijelovima Vojne krajine? Možemo li dizajn istraživanja upotrijebiti u ovom slučaju ne samo za samo za deskriptivno generiranje podataka nego ga fokusirati na komparativni oblik?

Buduća istraživanja i radovi koji će biti posvećeni političkom ponašanju birača i identifikaciji sa stankama na temelju identitetskih indikatora povezanim sa strukturalnim rascjepima u našem društvu i političkoj zajednici, otvorit će put prema novim rezultatima koji će komparacijom najsličnijih ili najrazličitijih slučajeva prikazati identitetska obilježja stanovnika naših županija.

\section{Literatura}

Peter BURNHAM - Karin GILLARD - Wyn GRANT - Zig LAYTON, Metode istraživanja politike, Fakultet političkih znanosti, Zagreb, 2001.

Manuel CASTELLS, Moć identiteta, Zagreb, 2002.

Furio CERUTTI, Identitet i politika, Zagreb, 2006.

Tihomir CIPEK, Oblikovanje hrvatskog nacionalnog identiteta. Primordijalni identitetski kod u ranoj hrvatskoj političkoj misli, Dijalog povijesničara-istoričara 4, Friedrich Naumann Stiftung, Zagreb, 2001, 59-77.

Rod HAGUE - Martin HARROP - Shaun BRESLIN, Komparativna vladavina i politika, Fakultet političkih znanosti, Zagreb, 2006. 
Manfred HÄTTICH, Temeljni pojmovi političke znanosti, Osijek-Zagreb-Split, 1996.

Ana LEMIĆ, Sela i stanovi na Velebitu. Svjedočanstva života od nastanka do nestanka, Zagreb, 2013.

Seymour M. LIPSET - Stein ROKKAN, Party Systems and Voter Alingmaents: CrossNational Perspectives, New York, 1967, 1- 64. http://janda.org/c24/Readings/ Lipset\&Rokkan/Lipset\&Rokkan.htm

Edgar MORIN, Misliti Europu, Durieux, Zagreb, 1995.

Antony SMITH, Nacionalni identitet, Biblioteka XX vek, Beograd, 1998.

Nikša STANČIĆ, Hrvatska nacija i nacionalizam u 19. i 20. stoljeću, Zagreb, 2002.

Milorad STUPAR, Pojam evropskog građanina, Filozofija i društvo, 3, Beograd, 2015, 9-26.

Vlado ŠAKIĆ - Renata FRANC - Ines IVIČIĆ - Jelena MARIČIĆ, Važnost sastavnica socijalnog identiteta: sličnosti i razlike stanovnika Like i Pokuplja sa stanovnicima ostalih hrvatskih regija, Identitet Like: korijeni $i$ razvitak, knjiga II, Institut društvenih znanosti Ivo Pilar-Područni centar Gospić, Zagreb-Gospić, 2009, 113 128.

John Charles TURNER - Katherine J. REYNOLDS, The social identity perspective in intergroup relations: Theories, themes and controversies, in Brown, R \& Gaertner, SL (ed.), Blackwell handbook of social psychology: Intergroup processes, Blackwell Publishing Ltd, Oxford, UK, 2001, 133-152.

Pavao RITTER VITEZOVIĆ, Oživjela Hrvatska, Zagreb, 1997.

Nenad ZAKOŠEK, Politički sustav Republike Hrvatske, Zagreb, 2002.

Sue WRIGHT, Jezična politika i jezično planiranje. Od nacionalizma do globalizacije, Zagreb, 2010.

http://www.enciklopedija.hr/natuknica.aspx?id=36410

http://www.enciklopedija.hr/natuknica.aspx?ID=65199

http://www.licko-senjska.hr/index.php/o-zupaniji/opci-podatci

http://www.likaplus.hr/ls_zupanija/politika/sto_pokazuje_zadnji_popis_stanovnistva/ default.aspx

http://www.sabor.hr/Default.aspx?sec=100

http://www.izbori.hr/106pre/rezult/2/rezultati.html 


\section{THE SPECIFICS OF THE IDENTITY OF THE PEOPLE OF PODGORJE - ITS FORMATION AND CHARACTERISTICS}

Summary

Studies of the identities of individual peoples or ethnic groups do not differ significantly in their methodological approach in as much in the fact that the feeling of the community, which is the basis of a collective identity, can be placed on completely different bases. The specifics, which determine an identity, are primarily the result of the historical and institutional context in which it has developed. Collective identities demonstrate an essential difference between political and cultural concepts of identity. However, the people of Podgorje have, for centuries, been the last line of defence of the Christian world and European civilisation from the Turks and the Islamisation of our continent. In the context of the Military Frontier as an institutional structure where they were on the bumper of Christianity, the people of Podgorje constructed an identity which we might be able to define by its characteristics not only as cultural but also as political.

Research questions: Can we therefore, in the role of the guardians of Christianity, define the identity of the people of Podgorje as a political identity which contains common political values which are expressed about the sense and directions of the project of a political community? Can these identity specifics also be analysed in the context of the political preference of the electoral body being Christian-conservatively orientated to the right?

Keywords: identity, people of Podgorje, guardians of Christianity 